\title{
History of the production and application of veterinary medications and biological preparations in Poland from the nineteenth century to 1945
}

\author{
JAROSŁAW SOBOLEWSKI
}

\begin{abstract}
Centre for Veterinary Sciences at the Nicolaus Copernicus University in Toruń, Gagarina Street 7, 87-100 Toruń, Poland
\end{abstract}
\section{Sobolewski J.}

\section{History of the production and application of veterinary medications and biological preparations} in Poland from the nineteenth century to 1945

\section{Summary}

The year 1899 can be regarded as the beginning of the production of medications for animals in the Polish territories, for it was then that biological preparations made at the Department of Hygiene of the Jagiellonian University in Kraków were first mentioned by the press. The interwar period saw the development of not only the veterinary and bioveterinary industry, but also legislation that regulated its functioning. Although very advanced for those times, those laws were also susceptible to different interpretations and could easily be circumvented. In 1939, there were 33 Polish companies producing synthetic preparations and 6 producing serums and vaccines. One serious problem of the Polish pharmaceutical industry was the deficiency of domestic investment capital. The foreign ownership of the pharmaceutical industry amounted to $30 \%$. Polish serums and vaccines for humans and animals fully covered the country's needs and represented the strongest branch of the domestic pharmaceutical industry (in 1939, the Polish production of medicines met $3 / 4$ of domestic demand). The development of industrial pharmacy in Poland was stopped by the outbreak of the Second World War. Many buildings were destroyed already at the beginning of the war in 1939. Post-war years showed that the foundations of the Polish pharmaceutical industry (including its veterinary branch) were solid. Polish pharmaceutical companies mostly recovered and sometimes even expanded their productive potential after the war.

Keywords: history of the veterinary science, veterinary pharmacy, veterinary science, bioveterinary industry

The year 1899 can be regarded as the beginning of the production of medications for animals in the Polish territories, for it was then that biological preparations made at the Department of Hygiene of the Jagiellonian University in Kraków were first mentioned by the press (14).

Until 1918, there were only seven enterprises producing veterinary medications. They were small laboratories preparing galenic formulations and simple medicines or sera and vaccines. These companies resumed their operation after the restoration of Poland's independence in 1918. The greatest problem the existing companies and start-ups was the lack of capital, which forced them to invite foreign investors (the foreign ownership of the Polish pharmaceutical industry reached $30 \%$ ). Another serious obstacle to the development of manufacturing was the lack of producers of specialized instruments, as well as the limited availability of chemical substances that were not produced in Poland (8-10). These problems were eventually overcome, and the small laboratories transformed into large industrial plants. The development of the production of veterinary medications was supported by the state, which financed the establishment of the National Institute for Scientific Agriculture [Państwowy Instytut Naukowego Gospodarstwa Wiejskiego (PINGW)] in Puławy. The main purpose of this institution was to develop strategies for fighting infectious diseases originating from foreign farm animals - and the production of sera and vaccines in Puławy served this aim $(5,12)$.

Among persons involved in building the Polish veterinary industry, it is important to mention Prof. Odo Bujwid, a student of Koch and Pasteur. His work was primarily in the diagnosis and fight against bovine tuberculosis and swine erysipelas. Bujwid opened the second centre for rabies vaccination in the world 
(Pasteur's was first). He made a pioneering contribution to the knowledge of bovine tuberculosis, and his use of tuberculin in the diagnosis of this disease was a major step in the fight against it. Bujwid described methods for the production of tuberculin and antierysipelas serum in many publications, which led to the development of other veterinary biological enterprises, such as the Department of Serum and Vaccine Production of the PINGW, Prof. Julian Nowak's SERO company, or the department of sera and vaccines of Henryk Klawe $(1,3,11)$. These four establishments provided a full supply of veterinary sera and vaccines. Polish biological preparations, aside from their moderate prices, were recognized for their high quality. Tests carried out by the National Institute of Hygiene as well as foreign institutions repeatedly confirmed that Polish sera had higher antibody levels and remained more stable than their foreign counterparts. The domestic veterinary biological industry made it possible to contain the spread of rinderpest in the early 1920s $(2,13)$.

Among the firms producing veterinary medications in Poland, three joint-stock companies were dominant: Towarzystwo Przemysłu ChemicznoFarmaceutycznego d. Mgr Klawe S.A., Zakłady Chemiczne Ludwik Spiess i Syn S.A., and ChemicznoFarmaceutyczne Zakłady Fr. Karpiński S.A. (4). Henryk Klawe, the founder of the first of these companies, was regarded as a reformer of the Polish pharmaceutical industry. Aside from traditional medications, he started the production of injectable drugs, as well as organic and biological preparations. In 1920 the company focused on veterinary pharmaceuticals. In order to meet growing demand, a property was purchased in Drwalew, where a serological and bacteriological research centre was established, providing a scientific and technological base for the serum and vaccine production plant. Efficient organization, an in-house research facility and high-quality products were the hallmark of the company and became a model for other Polish companies $(5,7)$. The high quality and attractive prices earned the company recognition among customers abroad, and its products were exported to France, Canada and the Middle East. Exhaustive information about the preparations was published in Weterynaria Współczesna [Contemporary Veterinary Medicine] and other professional journals, which made them popular in medical circles.

The companies of Ludwik Spiess and Franciszek Karpiński adopted a similar strategy, taking full advantage of scientific progress and innovative technologies. One difference, important for veterinary medicine, was that in the case of these companies the production of medicines for animals was not a priority. Both companies produced simple medications, easy to manufacture, which were also copied by many smaller companies.
Local drug manufacturers met a considerable portion of demand from practicing veterinarians, so even the smallest laboratories were very helpful in the treatment of animals.

The early development of the pharmaceutical industry in the Polish territories took place during the period of partitions, which significantly hampered its growth. The policies of the partition powers tended to restrict the expansion of Polish businesses. Three different legal systems existing in the Polish territories occupied by the three powers led to divergent interpretations of law after Poland's independence was restored in 1918. This made it essential for the Polish government to unify the law and to pass new legislation for the regulation and monitoring of production. Unfortunately, especially with regard to veterinary preparations, the new regulations were not always clearly phrased $(6,13)$. As a result, in 1935 there were only 47 registered medications, and most preparations were produced without any licence. The lack of monitoring could have a negative effect on the quality of products. Formally, every producer had to hold a licence from the Ministry of Internal Affairs, but in practice, the SERO company in Kraków operated until 1931 solely on the basis of a letter of intent from the Ministry of Agriculture (11).

The development of veterinary pharmaceuticals was possible thanks to the commitment of a group of scientists and industrialists. The above-mentioned Prof. Odo Bujwid was foremost among them. Also from Kraków was Julian Nowak, founder of the SERO company, professor at the Jagiellonian University and Prime Minister of Poland. Nowak deserves great credit for reducing the occurrence infectious diseases. After the restoration of independence, he was among the first to undertake the production of sera and vaccines, initially on the premises of the Jagiellonian University and later in his own facilities. He started production with his own capital and used personal income to equip the Department of Veterinary Medicine of the Jagiellonian University and to buy books for the academic library (11).

A large role in the creation of the Polish veterinary biological industry was played by Feliks Jaroszyński VS, head of the Serological Section of the PINGW in Puławy $(5,7)$. One of his first tasks was to fight rinderpest by organising and supervising the production of biological preparations. The campaign against rinderpest ended in complete success. Thanks to the work of Jaroszyński and others, Poland and Western Europe could continue to raise cattle. In 1935, the Serological Section of the PINGW became the Veterinary Department of the PINGW, headed by Dr. Kazimierz Zagrodzki, who worked with great energy to develop the department. The cost of the entire project was estimated at 5.7 million złotys. Thanks to the work of Dr. Zagrodzki, a refrigeration plant in Michałówka 
was built and equipped with laboratory and production apparatus. He also initiated the construction of the current headquarters of the National Veterinary Institute. In Klawe's company, the serum and vaccine production unit was run by Dr. Tadeusz Jastrzębski, who modelled it on a Czechoslovakian state serum and vaccine plant in Ivanovice na Hané (9).

The rise of the Polish pharmaceutical industry, including its veterinary component, was the accomplishment of several dozen small and large businesses, apothecary laboratories, manufacturers of galenic and veterinary biological preparations. The companies mentioned in this article paved the way for the development of industrial pharmaceuticals. Their activities were part of a general effort to develop domestic production of medications for animals based on materials and technologies developed in Poland. It was this goal, aside from economic benefits, that motivated scientists, industrialists and veterinarians involved in this process.

\section{References}

1. Bujwid O.: Osamotnienie 1932-1942. Wydawnictwo Literackie, Kraków 1990 2. Bujwid O.: Otrzymywanie i działanie surowic i szczepionek. Wydane nakładem własnym, Kraków 1912.
3. Bujwid O.: Uwagi o szczepionkach, ich stosowaniu i przyrządzaniu (z własnego Zakładu). Wiadom. Aptekarskie 1941, 8, 73-75.

4. Burda P.: WZF Polfa 175 lat tradycji i historii 1824-1999. WZF Polfa, Warszawa 1999

5. Grzęda M.: 80 lat działalności Zakładów Biowet w Puławach. Med. Weter. 2000, 56, 615-620.

6. Halicki T: Zarys organizacji Państwowej służby weterynaryjnej w Polsce. Wiadom. Wet. 1920, 33-36.

7. Kikta T.: Przemysł Farmaceutyczny w Polsce. PZWL, Warszawa 1972.

8. Kopeć S.: Od Barcikowskich i Czepczyńskich do PZZ Herbapol S.A. w Poznaniu. Herbapol, Poznań 2003.

9. Kurkowska-Bondarecka K.: Historia polskiego przemysłu farmaceutycznego. Zakład Wydawniczy Chempress, Gliwice 1995.

10. Łuczak Cz.: Położenie ludności polskiej w Kraju Warty 1939-1945. Wydawnictwo Poznańskie, Poznań 1987.

11. Nowak J.: Historia Instytutu Weterynarii i Medycyny Doświadczalnej Uniwersytetu Jagiellońskiego oraz Zakładu Produkcji Surowic i Szczepionek Weterynaryjnych. Drukarnia Uniwersytetu Jagiellońskiego, Kraków 1938.

12. Nowak J.: Rola służby weterynaryjnej w państwie współczesnem. Drukarnia Uniwersytetu Jagiellońskiego, Kraków 1935.

13. Przegląd najważniejszych ustaw, rozporządzeń, dotyczących aptekarstwa i gałęzi pokrewnych. Kalendarz Farmaceutyczny. Wydawnictwo Heroda, Warszawa 1930, 206.

14. Sobolewski J.: Rozwój produkcji oraz stosowanie leków i biopreparatów weterynaryjnych w Polsce od XIX wieku do 1945 roku. Praca dokt. SGGW, Warszawa 2006.

Corresponding author: Jarosław Sobolewski, DVM, PhD, Centrum Weterynarii Uniwersytetu Mikolaja Kopernika w Toruniu, ul. Gagarina 7, 87-100 Toruń, Poland; e-mail: jsobolewski@umk.pl 